\title{
Individual, Social and Psychological Characteristics of Smoking Cessation Behaviors: A Systematic Review
}

\author{
Susi Ari Kristina ${ }^{1}$, Vo Quang Trung ${ }^{2}$, Ni Putu Ayu Linda Permitasari ${ }^{3}$, Eliza Dwinta ${ }^{4} \&$ Faisal Rahman ${ }^{4}$ \\ ${ }^{1}$ Department of Pharmaceutics, Faculty of Pharmacy, Universitas Gadjah Mada, Indonesia \\ ${ }^{2}$ Department of Pharmacy Administration, Faculty of Pharmacy, Ho Chi Minh University of Medicine and \\ Pharmacy Ho Chi Minh City, Vietnam \\ ${ }^{3}$ Research Assistant, Department of Pharmaceutics, Faculty of Pharmacy, Universitas Gadjah Mada, Indonesia \\ ${ }^{4}$ Pharmacy Management Master Program, Faculty of Pharmacy, Universitas Gadjah Mada, Indonesia \\ Correspondence: Susi Ari Kristina, Department of Pharmaceutics, Faculty of Pharmacy, Universitas Gadjah Mada, \\ Indonesia. E-mail: susiari_k@ugm.ac.id
}

Received: August 3, 2018 Accepted: August 21, 2018 Online Published: September 3, 2018

doi:10.5539/gjhs.v10n10p55

URL: https://doi.org/10.5539/gjhs.v10n10p55

\begin{abstract}
About two thirds of active smokers want to quit smoking, yet not many people finally succeed in smoking cessation. Smoking cessation involve complex behaviors associated with individual, social and psychological characteristics as the key factors. Our objective is to review the studies about smoking cessation behavior correlated issues in order to find effective interventions of smoking cessation program. Terms and keywords pertinent to individual, social and psychological characteristics of smoking cessation behavior were used in a search of the electronic databases. Searches were limited to English language, included papers were: a) had clearly report the predictor variables related to smoking cessation behaviors, b) exclusively represent nation/s of study population, c) the time frame for the analysis was limited from 1998 to 2018. A result of 116 individual studies were retrieved at first and reviewed. After further inspection of references from the collected studies, 9 studies were approximately selected that met all inclusion criteria. The final studies consisted of five cross-sectional study and four cohort studies, conducted from different countries. There were several characteristics related to smoking cessation behavior including on levels of nicotine dependence, self-efficacy, smoking restriction and involve other smokers environment, motivation and educational background. Adjusted interventions due to those specific behaviors are needed in order to make more effective smoking cessation programs. Therefore, this study may provide new perspective for encouraged to decrease the amount of smokers worldwide through smoking cessation program.
\end{abstract}

Keywords: smoking cessation, behavior, smoking cessation predictors, quit smoking

\section{Introduction}

Smoking is one of the most public health issues yet to be solved worldwide (Goto, 2007). There is increasingly evidence of the harm to physically health by both active and passive tobacco smoking (McGhee, 2006). Tobacco smoking as the major factor attributed to non-communicable diseases incidence also becoming the most related cause of disease burden which are known to cause various cancers, respiratory, cardiovascular diseases and low birth weight (AL-Doghether, 2004; U.S. Department of Health and Human Services, 2014). It is estimated that death cause by smoking will escalate from 6.4 million in 2015 and 8.3 million in 2030 (Mathers, 2006). Currently, smoking is widely mentioned as the most unhealthy behavior in community.

Healthy behaviors are important requirements of health and disease, but general population find it difficult to perform these behaviors (Giles, 2016), including for smokers. Furthermore, smoking cessation and intention to quit involve complex behaviors associated with high addiction. Although the prevention of smoking initiation is important, the cessation of tobacco use is more urgent to prioritize (Gellert, 2012; Kim, 2014). Smoking-cessation interventions are a cost effective method to reduce the economic and health consequences of smoking. However, approximately two thirds of active smokers want to quit smoking, but not many people fully succeed (Centers for Disease Control and Prevention, 2011; Torchalla, 2011). Thus any clinical trials of innovative methods to change 
smoking cessation behavior aimed at quitting smoking are a high priority.

Current studies have explored smoker preferences in smoking in order to adapt the interventions to their individual needs (Regmi, 2018). Findings suggest that individual, social and psychological characteristics are the key determinants of smoking cessation behavior. These determinants can be intervened to increase the likelihood of success (Salloum, 2015). There is a need to gather information on smoker characteristics and their smoking cessation behaviors that affect the success of quitting smoking. Identifying the preferences and behavior of other smokers might help patients to choose an appropriate intervention that is more fit with patient preference and may increase the success rate of the cessation program (Baker, 2015).

Studies of smokers' behavior has been a focus of health economics research for many years (Goto, 2007) but commonly have been inconclusive, resulting in too few individual studies being analyzed, and the data of these methods yield have been inadequately informative (Siahpush, 2003). Besides that, available studies of smoking cessation behaviors were separated between individual, social and psychological characteristics. Therefore, our objective is to review the studies about smoking cessation behavior correlated issues. The areas of application were smoking cessation and smoking behavior to tobacco use. The application of this result study may explain smoking cessation behavior has the potential to establish specific related interventions for effective tobacco cessation programs.

\section{Methods}

This research is a systematic review to find out the individual, social and psychological characteristics related to smoking cessation behaviors of several related studies. There were 3 main steps to gain the data; first we identify and select related research about our topic. Second, we assess the retrieved research that met all eligibility criteria. Then third, we made the review and data extraction for each study.

\subsection{Study Identification}

Three electronic databases (PubMed, Science Direct, and Cochrane Database of Systematic Reviews) and Google Scholar were initially searched in June 2018. We conducted a systematic literature search for published studies in English that included the individual, social and psychological characteristics related to smoking cessation behaviors prior to recent years (1998-2018). Key words used for the search were as follows: individual OR social OR psychological AND smoking cessation OR smoking cessation behavior. Only articles that had explicitly defined measures those variables of interest were included, shown in Table 1.

Table 1. Inclusion and exclusion criteria for the reviewed articles

\begin{tabular}{|c|c|}
\hline Inclusion Criteria & Exclusion Criteria \\
\hline 1. Published in the English language & 1. Review articles, letters and comments \\
\hline 2. Time frame year from $1998-2018$ & 2. Report related with smoking cessation behaviors \\
\hline $\begin{array}{l}\text { 3. Report predictor variables related to smoking } \\
\text { cessation behaviors }\end{array}$ & from any intervention (behavioral or medical) \\
\hline 4. Exclusively represent nation/s of study population & \\
\hline 5. Available in full-text & \\
\hline
\end{tabular}

\subsection{Study Quality Assessment}

About 116 studies were initially collected and reviewed. After further tracking of references from the retrieved studies (due to full-text cannot be accessed by Universitas Gadjah Mada database, English language of the full-text were not available, report related with any intervention (behavioral or medical) to smoking cessation behavior, and duplicate topic of the articles), only 9 studies were finally analyzed that met all eligibility criteria. The PRISMA diagram of retrieved studies is shown in Figure 1. 


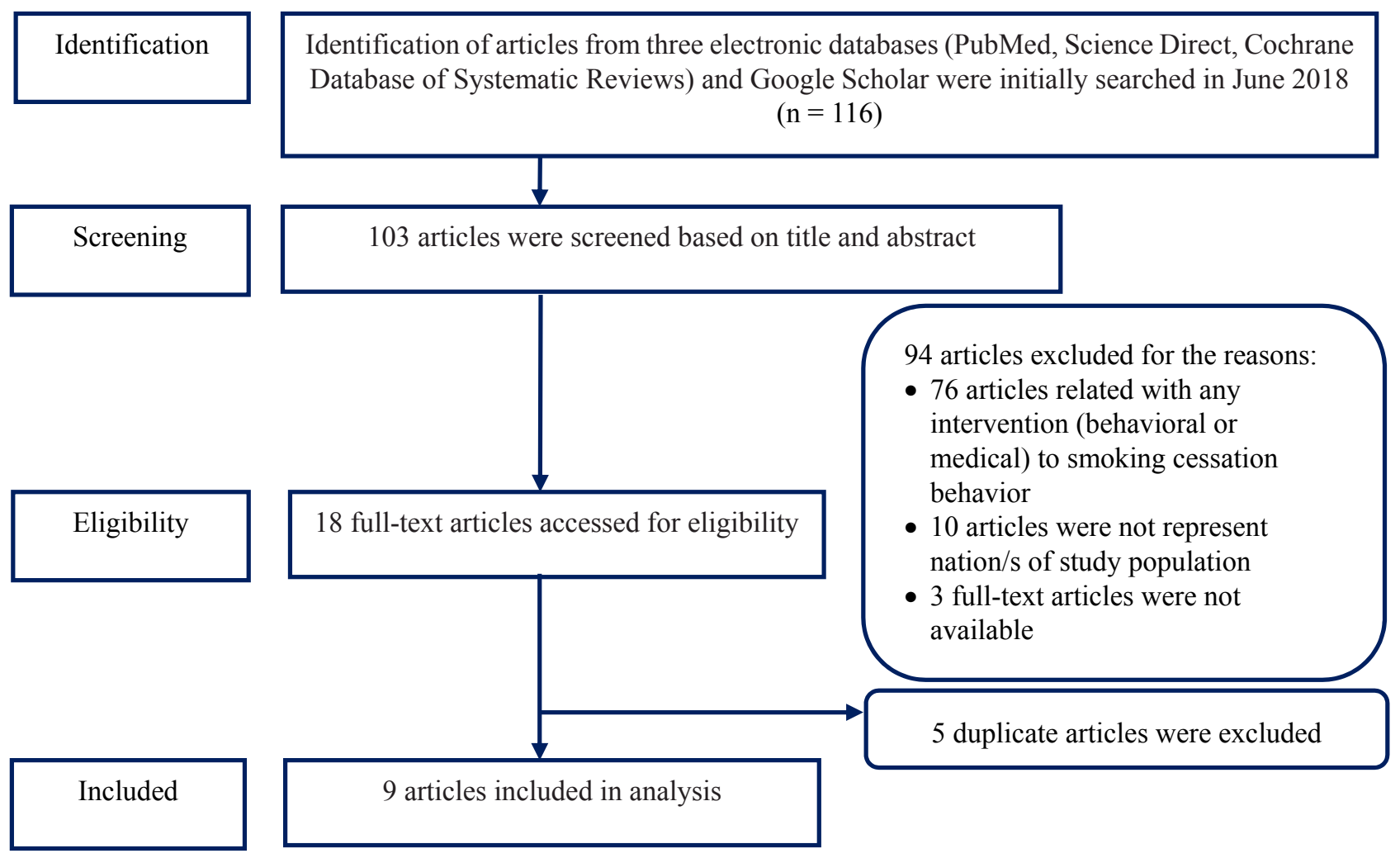

Figure 1. PRISMA diagram of retrieved studies

\subsection{Data Extraction}

Data were independently extracted by two independent researchers. Data extraction form included details of study design, research sample, countries, and selection of variables, instruments, approach and the result of each study. Non-agreement or any dissimilarity on the data extraction was resolved by discussion among the authors.

\section{Results}

\subsection{Details of Selected Studies}

The retrieved studies consisted of varied number of population and all conducted from different countries. Two studies were conducted in developing countries (Bangladesh and Thailand). The other seven studies were conducted in high income countries: Australia, USA, Denmark, Chicago, Japan and one study were conducted with population in multiple countries (Australia, Canada, UK, and USA). Mostly, 5 studies were published in the last ten years. We found a variety of sample characteristics within studies: one study was conduct for type 2 diabetes mellitus patients, one in patients with hypertension, one for mental illness and the rest were in healthy subjects. Four studies were published in sites that concerns on smoking addiction; four were published in a general public health and health technology assessment journal; and only one study published from nursing journal. The summary of characteristics of included studies can be seen in Table 2.

Table 2. Summary characteristics of included studies

\begin{tabular}{ll}
\hline Characteristic & Studies (n) \\
\hline Country of origin & 2 \\
Australia & 1 \\
USA & 1 \\
Denmark & 1 \\
Bangladesh & 1 \\
Thailand & 1 \\
\hline
\end{tabular}




\begin{tabular}{ll}
\hline Chicago & 1 \\
Japan & 1 \\
Multiple countries & 1 \\
\hline Year of Publication & 2 \\
$1998-2002$ & 2 \\
$2003-2007$ & 2 \\
$2008-2012$ & 3 \\
$2012-2016$ & 1 \\
\hline Smoking related disease sample & 1 \\
Type 2 diabetes mellitus & 1 \\
Hypertension & 6 \\
Mental illness & 2 \\
Healthy smokers & 2 \\
\hline Source of publication & \\
Addiction/tobacco/nicotine-related journals & 4 \\
Nursing journal & 1 \\
Public health/epidemiology journal & 2 \\
Health science and technology assessment journal & \\
\hline
\end{tabular}

\subsection{Methodological Characteristics}

The retrieved studies consisted of five cross-sectional study and four cohort studies. Most studies used multivariate logistic regression (8/9) as the correlation study analysis method and only one study used binary logistic regression models. The design sources variety between each study, like the Statistical Analysis System (SAS), STATA, SUDAAN, ITC-4 and SPPS. For the study approach, three studies reported used face-to-face structured interviews, two studies used mixture of face-to-face interview and self-administered questionnaire, one via self- administered questionnaire, one study administered survey via the internet online survey or email, one study conducted telephone interviews, and the remaining one administered face-to-face survey. The methodological characteristics for selected studies of this paper reported in Table 3.

Table 3. Methodology of selected studies

\begin{tabular}{|c|c|c|c|c|c|c|}
\hline Study & $\begin{array}{l}\text { Sample } \\
\text { size }\end{array}$ & Population & $\begin{array}{l}\text { Design } \\
\text { Country }\end{array}$ & Method & $\begin{array}{l}\text { Design } \\
\text { source }\end{array}$ & Approach \\
\hline $\begin{array}{l}\text { Siahpus et } \\
\text { al., } 2003\end{array}$ & 2,526 & $\begin{array}{l}\text { Smokers aged } \\
14 \text { years and } \\
\text { older }\end{array}$ & Australia & $\begin{array}{l}\text { Cross-sectional study } \\
\text { with multivariate } \\
\text { logistic regression }\end{array}$ & STATA & $\begin{array}{l}\text { Face-to-face interview } \\
\text { and self-administered } \\
\text { questionnaire }\end{array}$ \\
\hline $\begin{array}{l}\text { Hyland et } \\
\text { al., } 2006\end{array}$ & 6,682 & $\begin{array}{l}\text { Adult current } \\
\text { smokers }\end{array}$ & $\begin{array}{l}\text { Australia, } \\
\text { Canada, UK, } \\
\text { and USA }\end{array}$ & $\begin{array}{lr}\text { Prospective } & \text { cohort } \\
\text { study } & \text { with } \\
\text { multivariate } & \text { logistic } \\
\text { regression } & \end{array}$ & ITC-4 & $\begin{array}{l}\text { Face-to-face structured } \\
\text { interviews }\end{array}$ \\
\hline $\begin{array}{l}\text { Morimoto } \\
\text { et al., } 2010\end{array}$ & 441 & $\begin{array}{l}\text { Male } \\
\text { ever-smokers } \\
\text { with DMT2 }\end{array}$ & Japan & $\begin{array}{l}\text { Cross-sectional study } \\
\text { with multivariate } \\
\text { analysis }\end{array}$ & $\begin{array}{l}\text { SPSS } \\
\text { Japan Inc. } \\
\text { v. } 15.0\end{array}$ & $\begin{array}{l}\text { Face-to-face interview } \\
\text { and self-administered } \\
\text { questionnaire }\end{array}$ \\
\hline
\end{tabular}




\begin{tabular}{|c|c|c|c|c|c|c|}
\hline $\begin{array}{l}\text { Clark et al., } \\
1998\end{array}$ & 1,501 & $\begin{array}{l}\text { Smokers aged } 18 \\
\text { years or older }\end{array}$ & Chicago & $\begin{array}{lr}\text { Prospective } & \text { cohort } \\
\text { study with } & \text { multiple } \\
\text { logistic } & \text { regression } \\
\text { analyses } & \end{array}$ & Unclear & $\begin{array}{l}\text { Telephone } \\
\text { interviews }\end{array}$ \\
\hline $\begin{array}{l}\text { Tindle and } \\
\text { Shiffman, } \\
2011\end{array}$ & 2,040 & Current smokers & USA & $\begin{array}{l}\text { Cross-sectional with } \\
\text { multivariable logistic } \\
\text { regression analyses }\end{array}$ & $\begin{array}{l}\text { SUDAAN } \\
\text { v. } 10\end{array}$ & $\begin{array}{l}\text { Web-based } \\
\text { online survey }\end{array}$ \\
\hline $\begin{array}{l}\text { Abdullah } \\
\text { al., } 2015\end{array}$ & 1,861 & $\begin{array}{l}\text { Adult } \\
\text { smokers }\end{array}$ & Bangladesh & \begin{tabular}{lrr}
\multicolumn{2}{l}{ Prospective } & cohort \\
study with & binary \\
logistic & regression \\
models & &
\end{tabular} & SAS v. 9.4 & $\begin{array}{l}\text { Face-to-face } \\
\text { survey }\end{array}$ \\
\hline $\begin{array}{l}\text { Jianvitayakij } \\
\text { et al., } 2014\end{array}$ & 266 & $\begin{array}{lr}\text { Men } & \text { with } \\
\text { hypertension } & \text { who } \\
\text { smoked cigarettes }\end{array}$ & Thailand & $\begin{array}{l}\text { Cross-sectional with } \\
\text { multiple logistic } \\
\text { regression analysis }\end{array}$ & Unclear & $\begin{array}{l}\text { Face-to-face } \\
\text { structured } \\
\text { interviews }\end{array}$ \\
\hline $\begin{array}{l}\text { Metse et al., } \\
2016\end{array}$ & 754 & $\begin{array}{l}\text { Smokers admitted } \\
\text { to four psychiatric } \\
\text { inpatient facilities } \\
\text { in Australia }\end{array}$ & $\begin{array}{l}\text { New South } \\
\text { Wales (NSW), } \\
\text { Australia }\end{array}$ & $\begin{array}{l}\text { Cross-sectional } \\
\text { descriptive study with } \\
\text { multivariable logistic } \\
\text { regression analyses }\end{array}$ & $\begin{array}{l}\text { SPSS } \\
\text { Statistics v. } \\
22\end{array}$ & $\begin{array}{l}\text { Face-to-face } \\
\text { structured } \\
\text { interview }\end{array}$ \\
\hline $\begin{array}{l}\text { Osler and } \\
\text { Prescott, } 1998\end{array}$ & 2,554 & $\begin{array}{l}\text { Men and women } \\
\text { smokers aged } 30- \\
60 \text { years }\end{array}$ & $\begin{array}{l}\text { Copenhagen, } \\
\text { Denmark }\end{array}$ & $\begin{array}{l}\text { Cohort study with } \\
\text { multivariate regression } \\
\text { analysis }\end{array}$ & STATA & $\begin{array}{l}\text { Self- } \\
\text { administered } \\
\text { questionnaire }\end{array}$ \\
\hline
\end{tabular}

\subsection{Individual, Social and Psychological Characteristics of Smoking Cessation Behavior}

The selected studies were conducted for different objective/outcome measurements like seeing association of socio-demographic, behavioral and social environmental selected factors with successful quit smoking while another study conducted to find out the individual-level predictors of smoking cessation behaviors, psychosocial characteristics, and other factors of successful cessation differ with levels of motivation to quit for smokers who had and had not ever tried to quit.

From individual level predictors, lower levels of addiction on nicotine were the main factor that estimated future cessation among those that made a quit effort (Hyland, 2006). Frequency of someone smoking also become one of predictor variables of smoking cessation behavior which intermittent smokers were more likely than daily smokers to make a quit attempt (Tindle \& Shiffman, 2011). Perceived self-esteem in smoking cessation and concern about the health harm of smoking also became two determinants of smoking cessation for patients with hypertension (Jianvitayakij, 2014).

In term of social characteristics, the results of the Siahpus et al (2003) (Siahpush, 2003) study show that respondents who lived where smoking was not permitted and few or none of their friends smoked have greater odds of having quit smoking. In another hand, respondents who working outside the home which has no smoking restriction and those who not ready to quit within 6 months or earlier were less likely to have made a quit attempt in Abdullah et al (2015) study (Abdullah, 2015).

Meanwhile from psychosocial characteristics, ever smokers with high Free Child score and low educational background were more likely to currently smoke (Morimoto, 2010). Those who had tried to stop smoking were about twice as likely to think to quit, attempt to quit and actually quit smoking (Clark, 1998). Participants (with mental illness) who not living with other smokers and perceiving their health provider to be supportive was more likely to have quit for a longer duration (Metse, 2016). Osler and Prescott, (1998) reported smokers motivated to quit smoking are more likely to stop smoking and remain abstinent than smokers with no such motivation (Osler M and Prescott, 1998). The resume of the result of selected studies of this paper reported in Table 4. 
Table 4. Data extraction of selected studies

\begin{tabular}{|c|c|c|c|c|c|}
\hline References & $\begin{array}{l}\text { Outcome } \\
\text { measurements }\end{array}$ & $\begin{array}{l}\text { Predictor } \\
\text { variables }\end{array}$ & Main findings & Recommendation & $\begin{array}{l}\text { Strengths and } \\
\text { limitations }\end{array}$ \\
\hline $\begin{array}{l}\text { Siahpus et } \\
\text { al., } 2003\end{array}$ & $\begin{array}{l}\text { Association of } \\
\text { socio-demographic, } \\
\text { selected behavioral } \\
\text { and social } \\
\text { environmental } \\
\text { factors with } \\
\text { successful smoking } \\
\text { cessation }\end{array}$ & $\begin{array}{l}\text { Health risk, } \\
\text { households with } \\
\text { smoking } \\
\text { restrictions, social } \\
\text { environment } \\
\text { (smoker friends or } \\
\text { relatives), } \\
\text { education }\end{array}$ & $\begin{array}{l}\text { Respondents who } \\
\text { lived where } \\
\text { smoking was not } \\
\text { permitted (OR } \\
=5.3,95 \% \mathrm{CI} \text { : } \\
3.7-7.5) \text { and few } \\
\text { or none of their } \\
\text { friends smoked } \\
(\mathrm{OR}=4.1,95 \% \\
\mathrm{CI}: 2.7-6.2) \text { have } \\
\text { greater odds of } \\
\text { having quit } \\
\text { smoking }\end{array}$ & $\begin{array}{l}\text { Take into account } \\
\text { the social contexts } \\
\text { in which smoking } \\
\text { behavior takes } \\
\text { place }\end{array}$ & $\begin{array}{l}\text { Uncertain about the } \\
\text { temporal variables } \\
\text { (social-environment) }\end{array}$ \\
\hline $\begin{array}{l}\text { Hyland et } \\
\text { al., } 2006\end{array}$ & $\begin{array}{l}\text { Individual-level } \\
\text { predictors of } \\
\text { smoking cessation } \\
\text { behaviors }\end{array}$ & $\begin{array}{l}\text { Intention to quit, } \\
\text { duration of past } \\
\text { quit attempts, } \\
\text { smoking attitudes, } \\
\text { nicotine } \\
\text { dependence, age }\end{array}$ & $\begin{array}{l}\text { Lower levels of } \\
\text { nicotine } \\
\text { dependence were } \\
\text { the main factor } \\
\text { that predicted } \\
\text { future cessation } \\
\text { among those that } \\
\text { made a quit } \\
\text { attempt }(\mathrm{p}<0.05)\end{array}$ & $\mathrm{NM}$ & $\begin{array}{l}\text { Involvement of } \\
\text { multiple countries, } \\
\text { representative } \\
\text { samples, fluctuation } \\
\text { rate of result }\end{array}$ \\
\hline $\begin{array}{l}\text { Morimoto et } \\
\text { al., } 2010\end{array}$ & $\begin{array}{l}\text { Psychosocial } \\
\text { characteristics of } \\
\text { smoking cessation } \\
\text { behavior in DMT2 } \\
\text { patients }\end{array}$ & $\begin{array}{l}\text { Egogram (five ego } \\
\text { states : the Critical } \\
\text { parent, Nurturing } \\
\text { parent, Adult, Free } \\
\text { child and Adapted } \\
\text { child). }\end{array}$ & $\begin{array}{l}\text { Ever smokers with } \\
\text { high Free Child } \\
\text { score (OR }=3.12 \text {, } \\
95 \% \text { CI: } \\
1.97-4.97) \text {, low } \\
\text { educational } \\
\text { background } \\
(\mathrm{OR}=3.02,95 \% \\
\mathrm{CI}: 1.73-5.28) \\
\text { more likely to } \\
\text { currently smoke }\end{array}$ & $\begin{array}{l}\text { There is a need to } \\
\text { develop a } \\
\text { smoking cessation } \\
\text { program and } \\
\text { strong family } \\
\text { support for patient } \\
\text { DMT2 with high } \\
\text { "Free Child" } \\
\text { scores and low } \\
\text { education level. }\end{array}$ & $\begin{array}{l}\text { Non-representative } \\
\text { sample, does not } \\
\text { prove causal } \\
\text { relationship }\end{array}$ \\
\hline $\begin{array}{l}\text { Clark et al., } \\
1998\end{array}$ & $\begin{array}{l}\text { Psychosocial } \\
\text { characteristics of } \\
\text { smokers who had } \\
\text { and had not ever } \\
\text { tried to quit }\end{array}$ & $\begin{array}{l}\text { Planning to quit, } \\
\text { attempting to quit, } \\
\text { and quitting } \\
\text { smoking }\end{array}$ & $\begin{array}{l}\text { Those who had } \\
\text { tried to quit were } \\
\text { about twice as } \\
\text { likely to plan to } \\
\text { quit, attempt to } \\
\text { quit and actually } \\
\text { quit smoking } \\
(95 \% \mathrm{CI})\end{array}$ & $\begin{array}{l}\text { The potential } \\
\text { importance of } \\
\text { targeting } \\
\text { intervention } \\
\text { according to } \\
\text { whether or not } \\
\text { smokers have } \\
\text { made a prior quit } \\
\text { attempt. }\end{array}$ & $\begin{array}{l}\text { Generalization of } \\
\text { sample does not use } \\
\text { specific time frame } \\
\text { and stage of quit } \\
\text { trial }\end{array}$ \\
\hline $\begin{array}{l}\text { Tindle and } \\
\text { Shiffman, } \\
2011\end{array}$ & $\begin{array}{l}\text { Smoking cessation } \\
\text { behavior among } \\
\text { intermittent } \\
\text { smokers (ITS) } \\
\text { versus daily } \\
\text { smokers (DS) }\end{array}$ & $\begin{array}{l}\text { Personal } \\
\text { characteristics, quit } \\
\text { attempts, quit } \\
\text { success, and use of } \\
\text { quit aids among } \\
\text { groups }\end{array}$ & $\begin{array}{l}\text { All ITS were more } \\
\text { likely than were } \\
\text { DS to make a quit } \\
\text { attempt }(\mathrm{OR}= \\
1.60,95 \% \mathrm{CI}= \\
1.42-1.80)\end{array}$ & $\begin{array}{l}\text { External cues may } \\
\text { play a particularly } \\
\text { significant role in } \\
\text { the difficulties } \\
\text { that ITS have with } \\
\text { quitting. }\end{array}$ & $\mathrm{NM}$ \\
\hline
\end{tabular}




\begin{tabular}{|c|c|c|c|c|c|}
\hline $\begin{array}{l}\text { Abdullah et } \\
\text { al., } 2015\end{array}$ & $\begin{array}{l}\text { Factors associated } \\
\text { with smoking } \\
\text { cessation behavior } \\
\text { in adult }\end{array}$ & $\begin{array}{l}\text { Socio-demographic } \\
\text { characteristics as } \\
\text { well as behavioral, } \\
\text { cognitive, } \\
\text { attitudinal, } \\
\text { environmental and } \\
\text { motivational } \\
\text { measures }\end{array}$ & $\begin{array}{l}\text { Respondents who } \\
\text { working outside } \\
\text { the home (OR= } \\
0.62) \text { and made a } \\
\text { quit attempt not so } \\
\text { recently ( } 6 \text { months } \\
\text { ago or earlier, } \\
\text { OR=0.23, } \\
\text { p }<0.001) \text { were less } \\
\text { likely to have } \\
\text { made a quit } \\
\text { attempt }\end{array}$ & $\begin{array}{l}\text { Population based } \\
\text { smoking cessation } \\
\text { programs should } \\
\text { take into } \\
\text { consideration in } \\
\text { the design of } \\
\text { smoking cessation } \\
\text { interventions }\end{array}$ & $\begin{array}{l}\text { Periodical } \\
\text { observation, limited } \\
\text { to daily smokers } \\
\text { only, limited follow } \\
\text { up time analysis } \\
\text { risk. }\end{array}$ \\
\hline $\begin{array}{l}\text { Jianvitayakij } \\
\text { et al., } 2014\end{array}$ & $\begin{array}{l}\text { Factors and social } \\
\text { support for } \\
\text { smoking cessation } \\
\text { that predict } \\
\text { smoking cessation } \\
\text { behaviour among } \\
\text { male smokers with } \\
\text { hypertension (HT) }\end{array}$ & $\begin{array}{l}\text { Personal } \\
\text { information, } \\
\text { nicotine } \\
\text { dependence, the } \\
\text { perceived risks and } \\
\text { benefits, the } \\
\text { self-efficacy } \\
\text { inventory, and the } \\
\text { partner interaction. }\end{array}$ & $\begin{array}{l}\text { Perceived } \\
\text { self-efficacy in } \\
\text { smoking cessation } \\
\text { and concern about } \\
\text { the harm of } \\
\text { smoking became } \\
\text { two significant } \\
\text { predictors of } \\
\text { smoking cessation } \\
(\mathrm{OR}=1.71,95 \% \\
\mathrm{CI}=1.28-2.29)\end{array}$ & $\begin{array}{l}\text { Smoking } \\
\text { cessation } \\
\text { programs for } \\
\text { smokers with HT } \\
\text { may include } \\
\text { measures to } \\
\text { enhance } \\
\text { self-efficacy and } \\
\text { emphasize the } \\
\text { harmful effects of } \\
\text { smoking }\end{array}$ & $\begin{array}{l}\text { Non-representative } \\
\text { sample, cross } \\
\text { cultural issues from } \\
\text { instruments different } \\
\text { language }\end{array}$ \\
\hline $\begin{array}{l}\text { Metse et al., } \\
2016\end{array}$ & $\begin{array}{l}\text { Smoking and } \\
\text { environmental } \\
\text { characteristics } \\
\text { associated with } \\
\text { recent quitting } \\
\text { behaviour and } \\
\text { motivation }\end{array}$ & $\begin{array}{l}\text { Physical and social } \\
\text { environmental } \\
\text { characteristics }\end{array}$ & $\begin{array}{l}\text { Participants not } \\
\text { living with other } \\
\text { smokers (OR = } \\
\text { 2.02) and } \\
\text { perceiving their } \\
\text { psychiatrist to be } \\
\text { supportive was } \\
\text { more likely to have } \\
\text { quit for a longer } \\
\text { duration }(\mathrm{OR}= \\
2.83,95 \% \mathrm{CI}: 1.64 \\
-4.88, \mathrm{p}<0.001)\end{array}$ & $\begin{array}{l}\text { Modifiable } \\
\text { characteristics of } \\
\text { the physical and } \\
\text { social } \\
\text { environment } \\
\text { should be } \\
\text { considered in } \\
\text { smoking } \\
\text { cessation } \\
\text { interventions for } \\
\text { persons with a } \\
\text { mental illness. }\end{array}$ & $\begin{array}{l}\text { Large and diverse } \\
\text { sample of smokers } \\
\text { with a mental } \\
\text { illness, relatively } \\
\text { high consent rate, } \\
\text { overestimation }\end{array}$ \\
\hline $\begin{array}{l}\text { Osler and } \\
\text { Prescott, } \\
1998\end{array}$ & $\begin{array}{l}\text { Determinants of } \\
\text { successful } \\
\text { cessation differ } \\
\text { with levels of } \\
\text { motivation to stop }\end{array}$ & $\begin{array}{l}\text { Psychosocial, } \\
\text { behavior, and } \\
\text { health factors }\end{array}$ & $\begin{array}{l}\text { Smokers motivated } \\
\text { to stop are more } \\
\text { likely to quit and } \\
\text { remain abstinent } \\
\text { than smokers with } \\
\text { no such motivation } \\
(\mathrm{OR}=2.28,95 \% \\
\text { CI: } 1.33-3.77)\end{array}$ & \begin{tabular}{l} 
Factors predict \\
cessation \\
irrespective of \\
\multicolumn{2}{c}{ smokers' baseline } \\
motivation to \\
stop should be \\
considered in \\
setting \\
smoking \\
cessation \\
programs
\end{tabular} & $\begin{array}{l}\text { High rates of loss to } \\
\text { follow up }\end{array}$ \\
\hline
\end{tabular}

NM: Not mentioned.

\section{Discussion}

Tobacco smoke is the leading cause of preventable diseases and premature mortality worldwide. Effective intervention need to involve not only smokers who intend to quit but also their supportive family, friends, and implementing smoke-free area policies that support individual cessation. Current smoking cessation guidelines suggest that treatment should include both behavioral intervention and pharmacotherapy (e.g. nicotine replacement therapy) (Roberts, 2013). There is also a need regular treatment or intervention due to relapse 
occurrence. For this reason, the psychosocial dimension of the addiction should be treated (Koyun and Eroğlu, 2014).

Nevertheless, intensive interventions combined behavioral treatment with pharmacotherapy, long-term abstinence rates have only at range 20-35\% success rate (Alterman, 2001). Such evidences of constantly low abstinence predict the need for creating new and more innovative tobacco cessation programs. Socio-economic characteristics, smoking-related behaviors, and worksite environments significantly affect smoker capability to quit.

Our review findings from individual characteristics, lower levels of nicotine dependence (Hyland, 2006), frequency of intermittent smokers of someone smoking (Tindle \& Shiffman, 2011), and smokers who perceived self-efficacy in smoking quit attempt and concern about the health consequences of smoking (Jianvitayakij, 2014) were the main predictors of smoking cessation behavior that likely predicted succeed of future cessation among those that made a quit attempt. Therefore, it is important to gather information on smoker characteristics that influence the success of cessation (West, 2017). Smoking quit-line from various health providers should be organized to treat cessation relaps and to improve strategies to increase public awareness on smoking harm (Lee \& Kahende, 2007).

Meanwhile for social characteristics, respondents who lived where smoking was not permitted with few or none of their friends smoked have greater odds of having quit smoking (Siahpush, 2003) but who working outside the home which has no smoking restriction and those who made a quit attempt less than 6 months or earlier were less likely to have made a quit attempt (Abdullah, 2015). For this term, effective smoking cessation program may need to let in family members (Lee and Kahende, 2007). Restricted availability and regulations at the working places also increase the likelihood of cessation rate as in Hammar and Carlsson (2005) study result show the substantial role of self-efficacy; smokers who have higher intention to quit are more likely to abstinent if a stricter regulation is implemented (Hammar \& Carlsson, 2005).

In psychosocial characteristics, low educational background were more likely to currently smoke (Morimoto, 2010) but those who had tried to quit (Clark, 1998) and smokers that already motivated (by themselves and support others) to quit are more likely to stop smoking and remain abstinent than smokers with no such motivation (Metse, 2016; Osler \& Prescott, 1998). One of strategy which smokers received advice from their family or who perceive the health risks are more likely to reach abstinent (Hammar \& Carlsson, 2005).

Effective interventions can generate long-term impact on cessation compared to smokers without treatment. Whatever the intervention may give to the smokers, there should be notice that a need of regular treatment or intervention due to relapse occurrence. A massive strategy by providing cessation quite-line in all health facilities could potentially enhance the coverage including those who are initially unwilling to quit (Baker, 2015). It should be noted also that each of those smoking cessation behaviors does not stand alone. Individual may have several behavioral characteristics at once that can support or decrease the success of the intervention.

Potential limitations need to be addressed in interpreting the findings of this review. The heterogeneity of the studies' method made it hard in summarizing the review, so we are suggest to do analyzing for the accurate and particular method of related studies in the near future, if possible. The result study may different and vary across regions because it was general factors of smoking cessation behavior for people in certain places and specific conditions, hoping it gave an overview for other countries about their possible/effective smoking cessation programs. Further research is needed on the smoking cessation behavior of populations with other special conditions in order to recommend a more comprehensive cessation intervention according to those needs.

\section{Conclusions}

Smoking cessation behaviors are different for each individuals and specific populations. Adjusted interventions due to those specific behaviors are needed in order to make more effective smoking cessation programs. Therefore, it can provide new perspective for encouraged to decrease the amount of smokers worldwide through smoking cessation program.

\section{Competing Interests Statement}

The authors declare that there are no competing or potential conflicts of interest.

\section{References}

Abdullah, A. S., Driezen, P., Quah, A. C., Nargis, N., \& Fong, G. T. (2015). Predictors of smoking cessation behavior among Bangladeshi adults: findings from ITC Bangladesh survey. Tobacco induced diseases, 13(1), 23. https://doi.org/10.1186/s12971-015-0050-y

AL-Doghether, M. H. (2004). The Behavioral Interventions for Smoking Cessation. Asia Pacific Family Medicine, 
$3(1-2), 19-28$

Alterman AI, G. P., \& Mulvaney F. (2001). Short- and long-term smoking cessation for three levels of intensity of behavioral treatment. Psychology of Addictive Behaviors, 15(3), 261-264. https://doi.org/10.1037/0893-164X.15.3.261

Baker, T. B., Collins, L. M., Mermelstein, R., Piper, M. E., Schlam, T. R., Cook, J. W., ... \& Loh, W. Y. (2016). Enhancing the effectiveness of smoking treatment research: conceptual bases and progress. Addiction, 111(1), 107-116. https://doi.org/10.1111/add.13154

Centers for Disease Control and Prevention. (2011). Quitting Smoking among Adults-United States, 2001-2010. MMWR (Morbidity and Mortality Weekly Reports) (Vol. 60, pp. 1513-1519).

Clark, M. A., Kviz, F. J., Crittenden, K. S., \& Warnecke, R. B. (1998). Psychosocial factors and smoking cessation behaviors among smokers who have and have not ever tried to quit. Health Education Research, 13(1), 145-153. https://doi.org/10.1093/her/13.1.145

Gellert, C., Schöttker, B., \& Brenner, H. (2012). Smoking and all-cause mortality in older people: systematic review and meta-analysis. Archives of internal medicine, 172(11), 837-844. https://doi.org/10.1001/archinternmed.2012.1397

Giles, E. L., Becker, F., Ternent, L., Sniehotta, F. F., McColl, E., \& Adams, J. (2016). Acceptability of financial incentives for health behaviours: a discrete choice experiment. PLoS One, 11(6), e0157403. https://doi.org/10.1371/journal.pone.0157403

Goto, R., Nishimura, S., \& Ida, T. (2007). Discrete choice experiment of smoking cessation behaviour in Japan. Tobacco control, 16(5), 336-343.https://doi.org/10.1136/tc.2006.019281

Hammar, H., \& Carlsson, F. (2005). Smokers' expectations to quit smoking. Health economics, 14(3), 257-267.

Hyland, A., Borland, R., Li, Q., Yong, H. H., McNeill, A., Fong, G. T., ... \& Cummings, K. M. (2006). Individual-level predictors of cessation behaviours among participants in the International Tobacco Control (ITC) Four Country Survey. Tobacco control, 15(suppl 3), iii83-iii94. https://doi.org/10.1136/tc.2005.013516

Jianvitayakij, S., Panpakdee, O., Malathum, P., Duffy, S., \& Viwatwongkasem, C. (2014). Factors influencing smoking cessation behavior among Thai male smokers with hypertension. Pacific Rim International Journal of Nursing Research, 18(2), 100-110.

Youngmee, K., \& Won-Kyung, C. H. O. (2014). Factors Associated with Successful Smoking Cessation in Korean Adult Males: Findings from a National Survey. Iranian journal of public health, 43(11), 1486.

Koyun, A., \& Eroglu, K. (2014). The transtheoretical model use for smoking cessation. European Journal of Research on Education, 130-134.

Lee, C. W., \& Kahende, J. (2007). Factors associated with successful smoking cessation in the United States, 2000. American Journal of Public Health, 97(8), 1503-1509. https://doi.org/10.2105/AJPH.2005.083527

Mathers, C. D., \& Loncar, D. (2006). Projections of global mortality and burden of disease from 2002 to 2030. PLoS medicine, 3(11), e442. https://doi.org/10.1371/journal.pmed.0030442

Mcghee, S. M., Ho, L. M., Lapsley, H. M., Chau, J., Cheung, W. L., Ho, S. Y., ... \& Hedley, A. J. (2006). Cost of tobacco-related diseases, including passive smoking, in Hong Kong. Tobacco control, 15(2), 125-130. https://doi.org/10.1136/tc.2005.013292

Metse, A. P., Wiggers, J., Wye, P., Moore, L., Clancy, R., Wolfenden, L., ... \& Bowman, J. A. (2016). Smoking and environmental characteristics of smokers with a mental illness, and associations with quitting behaviour and motivation; a cross sectional study. BMC public health, 16(1), 332. https://doi.org/10.1186/s12889-016-2969-1

Morimoto, A., Miyamatsu, N., Okamura, T., Hozawa, A., Kadota, A., Morinaga, M., ... \& Ueshima, H. (2010). What psychosocial characteristics are associated with smoking cessation behavior and readiness to quit smoking among japanese male ever-smokers with type 2 diabetes mellitus?. Journal of atherosclerosis and thrombosis, 17(4), 361-368. https://doi.org/10.5551/jat.3194

Osler, M., \& Prescott, E. (1998). Psychosocial, behavioural, and health determinants of successful smoking cessation: a longitudinal study of Danish adults. Tobacco control, 7(3), 262-267. https://doi.org/10.1136/tc.7.3.262

Regmi, K., Kaphle, D., Timilsina, S., \& Tuha, N. A. A. (2018). Application of discrete-choice experiment methods 
in tobacco control: a systematic review. PharmacoEconomics-open, 1-13. https://doi.org/10.1007/s41669-017-0025-4

Roberts, N. J., Kerr, S. M., \& Smith, S. M. (2013). Behavioral interventions associated with smoking cessation in the treatment of tobacco use. Health services insights, 6, HSI-S11092. https://doi.org/10.4137/HSI.S11092

Salloum, R. G., Abbyad, C. W., Kohler, R. E., Kratka, A. K., Oh, L., \& Wood, K. A. (2014). Assessing preferences for a university-based smoking cessation program in Lebanon: a discrete choice experiment. Nicotine \& Tobacco Research, 17(5), 580-585. https://doi.org/10.1093/ntr/ntu188

Siahpush, M., Borland, R., \& Scollo, M. (2003). Factors associated with smoking cessation in a national sample of Australians. Nicotine \& Tobacco Research, 5(4), 597-602. https://doi.org/10.1080/1462220031000118711

Tindle, H. A., \& Shiffman, S. (2011). Smoking cessation behavior among intermittent smokers versus daily smokers. American journal of public health, 101(7), e1-e3. https://doi.org/10.2105/AJPH.2011.300186

Torchalla, I., Okoli, C. T., Hemsing, N., \& Greaves, L. (2011). Gender differences in smoking behaviour and cessation. Journal of Smoking Cessation, 6(1), 9-16.

U.S. Department of Health and Human Services. (2014). The Health Consequences of Smoking-50 Years of Progress: A Report of the Surgeon General. Atlanta, GA: U.S. Department of Health and Human Services, Centers for Disease Control and Prevention, National Center for Chronic Disease Prevention and Health Promotion, Office on Smoking and Health.

West, R., Evins, A. E., Benowitz, N. L., Russ, C., McRae, T., Lawrence, D., ... \& Anthenelli, R. M. (2018). Factors associated with the efficacy of smoking cessation treatments and predictors of smoking abstinence in EAGLES. Addiction. https://doi.org/10.1111/add.14208

\section{CopyrightsFta}

Copyright for this article is retained by the author(s), with first publication rights granted to the journal.

This is an open-access article distributed under the terms and conditions of the Creative Commons Attribution license (http://creativecommons.org/licenses/by/4.0/). 